\title{
JOHN DEVITT STRINGFELLOW PENDLEBURY
}

\author{
(With Plate 2)
}

I

Born in London on 12 October, I904, and educated at Winchester and Pembroke College, Cambridge, John Pendlebury was early attracted to Greek studies. While still at school, he spent an Easter vacation in the Ægean, and as Cambridge University Student of the British School (1927-28) he reached Athens by way of the Balkan countries and Constantinople. In Crete his exceptional qualities were at once recognised by Sir Arthur Evans, but his first experience of excavation was with W. A. Heurtley in Macedonia. In I 928 he married Miss Hilda White, a fellow student of the School, who shared all his work henceforward. In the same winter he joined the staff of the Egypt Excavation Society at Arment, and thereafter at Tell-el-Amarna, whither he returned as Director in 1930 for seven years, spending the offseasons in Crete for a while as Curator of Knossos, and publishing his Handbook to the Palace of Knossos in 1933, and The Archaeology of Crete in 1939. His Aegyptiaca had already appeared in 1930. In 1939 he completed his excavation of the highland Cretan site, Karphi Lasithi; and when war seemed imminent he was enrolled in the Reserve of Officers. After cavalry training, he was sent to Crete as Vice-Consul at Candia, and became liaison officer with the Greek forces. Here he was wounded and killed during the invasion.

An appreciation of his work as a scholar, by S. R. K. Glanville, appeared in The Fournal of Egyptian Archaeology, vol. 28, 1942, p. 6i.

J. L. M.

John Pendlebury when I met him at Mycenae on his first visit to Greece-before he went up to Cambridge - told me then of his desire and intention to become an archaeologist and that he had already begun to learn Egyptian hieroglyphs. On that occasion, too, he much impressed me by his anxiety to see things for himself, so as to be able to form a fresh, independent, first-hand idea of them.

Thus, though he obtained a first class, with distinction in archaeology, in the Classical Tripos at Cambridge, it is not surprising that his first publication should have been concerned with Egyptology. This, Aegyptiaca, displayed both his original interest in Egyptology and also his desire to see the actual objects which he described and discussed. This book, too, gave him an opportunity for combining his early attraction towards Egypt with his strong and growing interest in the earliest days of Greece. He catalogued, according to the sites at which they had been found in Greece, all the Egyptian objects of which he could obtain knowledge, and so provided Greek archaeologists with trustworthy descriptions and accurate dates. The dating of such objects is, of course, of paramount importance for the dating both of the strata in which they were found and of the other objects found with them, and helps to build up the chronology of early Greece.

After taking his degree, Pendlebury began that series of journeys and explorations in the Near East which was to confirm his reputation as an archaeologist. After travel in Greece, and taking part in Heurtley's excavations in Macedonia, he not unnaturally turned to Egypt. There, at the start as member of the party excavating at Amarna and afterwards as leader of it, he learnt at first-hand the art and culture of the Amarna period. By his publications of the results of the excavations which he carried on for seven years he showed that he was able to place the Amarna culture in its right perspective both from the Egyptian and from what may 
be termed the international aspect. In his contributions to the official and scientific account of the Amarna excavations he recorded the archaeological facts simply and clearly, and interpreted them lucidly, and in doing so displayed two of the essential qualities of a good excavator. At the same time his small book on Amarna gave the world at large an easily intelligible and straightforward account of Akhenaton's city, its culture, and its life. It is not every archaeologist who can convey readily to the "man in the street" the meaning and the historical and cultural value of his excavations.

Pendlebury was from the beginning essentially a field archaeologist, and it was in Crete that he found full play for his talents. He had already visited and travelled in Crete, and when in the season 1929-3o he became Curator of Knossos in succession to Dr. Duncan Mackenzie, he took every advantage of his opportunities. He first assisted Sir Arthur Evans in his last supplementary investigations in and around the Palace of Minos, and at the same time by wide travels throughout the island he enlarged his knowledge of everything pertaining to ancient Crete. Here his excellent knowledge of things Minoan and post-Minoan enabled him to form a good idea of the importance of remains observed on the surface and to interpret accounts given by Gretans of accidental discoveries of antiquities.

His Knossian work is represented by an admirable excavation report on proto-palatial houses, written in conjunction with his wife, by his Handbook to the Palace of Minos, and by his detailed description of the Stratigraphic Museum at Knossos. The Handbook to the Palace is an admirable piece of work, concise and clear. It answers most of the questions which an intelligent visitor would wish to ask, and at the same time provides the archaeologist with a sure foundation for further study. His account of the Stratigraphic Museum is now invaluable, in view of the disturbances caused by the war, and irreplaceable. It presents the stratigraphic evidence for the dating of the different sections of the Palace and of their strata, and enables the archaeologist to check thereby the published accounts and plans. It gives the basic essential facts on which the chronology is founded, and is an excellent illustration of Pendlebury's intimate knowledge of the Palace and of his patience in sorting and recording an enormous number of pottery fragments. Thus the guides to the Palace and to its Stratigraphic Museum are indispensable adjuncts to Evans' monumental, but labyrinthine Palace of Minos.

In 1936 Pendlebury began a series of excavations in the Lasethi area which continued till 1939. These brought fresh and important information about the population and culture of the district at the very dawn of Minoan civilisation and again at its close, at the transition from the age of bronze to the age of iron, one of the darkest periods of Cretan history. Here Pendlebury, as always, wisely combined archaeological reconnaissance of the neighbourhood with excavation of the site chosen. The publications of the results of these excavations are models of their kind. They show the fine co-operative spirit which existed between the leader and his fellow-workers, and also his wide interest in anything which concerned the site. The excavation report, for instance, concludes with an account of the flora of Lasethi.

The climax, however, of Pendlebury's archaeological work is his Archaeology of Crete. This deals with all the ancient periods of the island, prehistoric and historic, and the remains of them which can still be observed or have been excavated. It collects into a comparatively small compass all that is known, and classifies the remains according to their periods. As the fruit of a personal archaeological survey of Crete carried out during many years, it shows Pendlebury's intimate acquaintance with all aspects of the island, its history, and its life. Especially noteworthy are the efforts made to trace the ancient routes, to note the harbours, and to record variations in the density of population from one period to another and to compare ancient with modern conditions. Pendlebury gives in this unpretentious, but most learned 
book a summary and a synthesis of Cretan archaeology which will long remain a standard work and will probably always be used by any scholar studying the history and archaeology of the island. Best of all is the fact that the book is the product of his own direct explorations and his own verifications of what had been observed previously. Here is an account of Crete not compiled in a library, but on the spot, and under the influence of fresh, personal investigation of the actual remains. There could be no better evidence than this book of what can be accomplished by field archaeology, by personal exploration without excavation, by combining knowledge and observation. It is an example which should be followed by anyone who in the future may wish to present a similar account of some district of Greece or of one of the islands. It had been hoped that Pendlebury would have turned his attention to one of the Cyclades, where so excellent an explorer would have found much of great interest. He had, indeed, begun, but fate prevented the completion of these plans.

His archaeological work is enough to place Pendlebury in the first rank as a field archaeologist. He was an excellent excavator, a keen and patient observer, and there has never been a better explorer of Crete, in which field he was the peer of Spratt and Evans.

A. J. B. WACE.

\section{III}

John Devitt Stringfellow Pendlebury, born on October 12, I904, died in Crete on or about 24 May, 194I. He had been placed on the reserve of officers in August 1939, and was gazetted Captain in May 1940. He was appointed British Vice-Consul at Candia in June, and on the arrival of British forces in Crete in November was made Liaison Officer with the Greek troops. The manner of his death is not known. It is certain however that towards the end of the resistance on the island, and when Heraklion was hard pressed, Pendlebury led a charge from the Canea Gate of the town, with the object of relieving hard-pressed Greek troops. It is possible that he was killed outright in this action, but more probable that he was badly wounded. A fellow-officer believes that he was taken back by his faithful Cretans to his house, presumably at Lasithi, where he died shortly after. It is also related that he led his last charge with his famous swordstick in his hand. I like to think this true, for such an heroic gesture would be characteristic.

The enduring impression of my first meeting with Pendlebury in his rooms at Pembroke in 1923 is the neatness and orderliness of the man, and an indefinable air of restrained power. He did not work, like the ordinary run of undergraduate, in a litter of texts, lexicons, papers, and notebooks, and he was always manifestly in training. My portrait of Pendlebury at nineteen is of a friendly athlete sitting on a hard chair with one book open, the book he was reading. It might be the Iliad or the latest volume of The Palace of Minos, or it might be Maurice Hewlett's Forest Lovers. In these formative years Pendlebury came to see the past through the spectacles of the romantic, or rather the chivalrous, and I believe that these sentiments grew with the years, until they crystallised into the shining core of the mature man who died defending Crete from the latest of a long line of invaders. This appeal of the chivalrous called to the heart and the mind with equal insistence. The Knighthood of Crete, of Egypt and of the Middle Ages beckoned and called to one of their kin, and never did man respond with more delight. Pendlebury was completely happy in his work, with that happiness which comes of the union of mind and emotion.

Pendlebury was an archaeologist in the grand tradition. Even before he left Winchester his mind was firmly set on following down the paths which Schliemann and Evans had blazed through the Heroic Age. Cambridge was a preparation for the field work on which he 
embarked as soon as he left the University, and though he read Classics with distinction, he did not show or admit much enthusiasm for the Greece and Rome of the Golden Age, any more than for textual criticism or Greek iambics. This is not to say that he lacked the capacities or the instincts of a good and careful scholar; all his work was sound and scholarly. But to him scholarship was an instrument to be used, not a vocation in itself.

To these gifts of intellect and qualities of imagination Pendlebury added exceptional physical stamina and athletic powers. The endurance and skill which earned him a Blue at Cambridge, where he jumped six feet against Oxford, a height not then exceeded since 1876 , stood him in good stead in his scientific work, and he could out-walk and out-jump any Cretan mountaineer. He took a singular pleasure in this athletic virtuosity, which indeed was his only vanity. For the rest I do not believe that he ever gave his archaeological achievements a thought; they were his life, and he lived it hard all the time, with an enthusiasm which those with whom he came in contact were impelled to share. Nothing he touched but sprang to vivid life. The following remarks of the fellow-officer already cited illustrate the effect of his joyous personality on an acquaintance who had nothing in common with his scientific work:

"He was a mine of information on Crete, and always had a good story to tell of every acre of the island. His love for the island seemed to be the great passion of his life, and he made everyone share it. There are many who knew him who are determined to go back there, to renew the pleasure to which he introduced them."

It was this enthusiasm for the present as well as the past which made Pendlebury so invigorating a companion, and a natural leader of men. The war and the opportunity for service brought to their highest expression the chivalrous and heroic instincts which appealed to him from the past. He died, as he had lived, a paladin.

Pendlebury married in 1928 Hilda White, a fellow student of the British School of Archaeology at Athens, his constant companion, with whom much of his work was done in collaboration. He leaves a boy and a girl.

Pierson Dixon.

\section{JAMES O. EWART.}

I 9 I 7-I 945 .

ONE who has taught Greek to Honours Classes for over thirty years has naturally taught many men of promise. It has been my sore fate to offer the tribute of a teacher and a friend to the memory of the two among all my students of whom I expected most. First it was James C. Watson, called amid universal acclaim to an important Chair at the age of 29 and killed in action as an Ordinary Seaman on H.M.S. Faguar in 1942. Now it is Colonel James O. Ewart, who fought unscathed from El Alamein to the Rhine, to be killed after the Armistice by a skidding car.

Ewart was born in I9I7. He was at George Watson's from 1929 to 1935, leaving as Dux. He entered Edinburgh University as Dundas Bursar in 1935, subsequently winning the Spence Bursary, the George Scott Travelling Scholarship, and the Mackenzie Scholarship in Classics and English Literature. Each summer vacation from 1934 onwards he spent travelling on the Continent, visiting in turn Germany, Czechoslovakia, Austria, Hungary and Bulgaria, and finally Greece, which he visited before his final year at Edinburgh, and again before the outbreak of the War, in the course of a study of Greek theatres which ranged from Sicily to Asia Minor. He spoke German, French, Italian and Greek.

Ewart was not a facile linguist, and he paid in hard work for the workmanlike grasp he 
B.S.A. XII.

Plate 2.

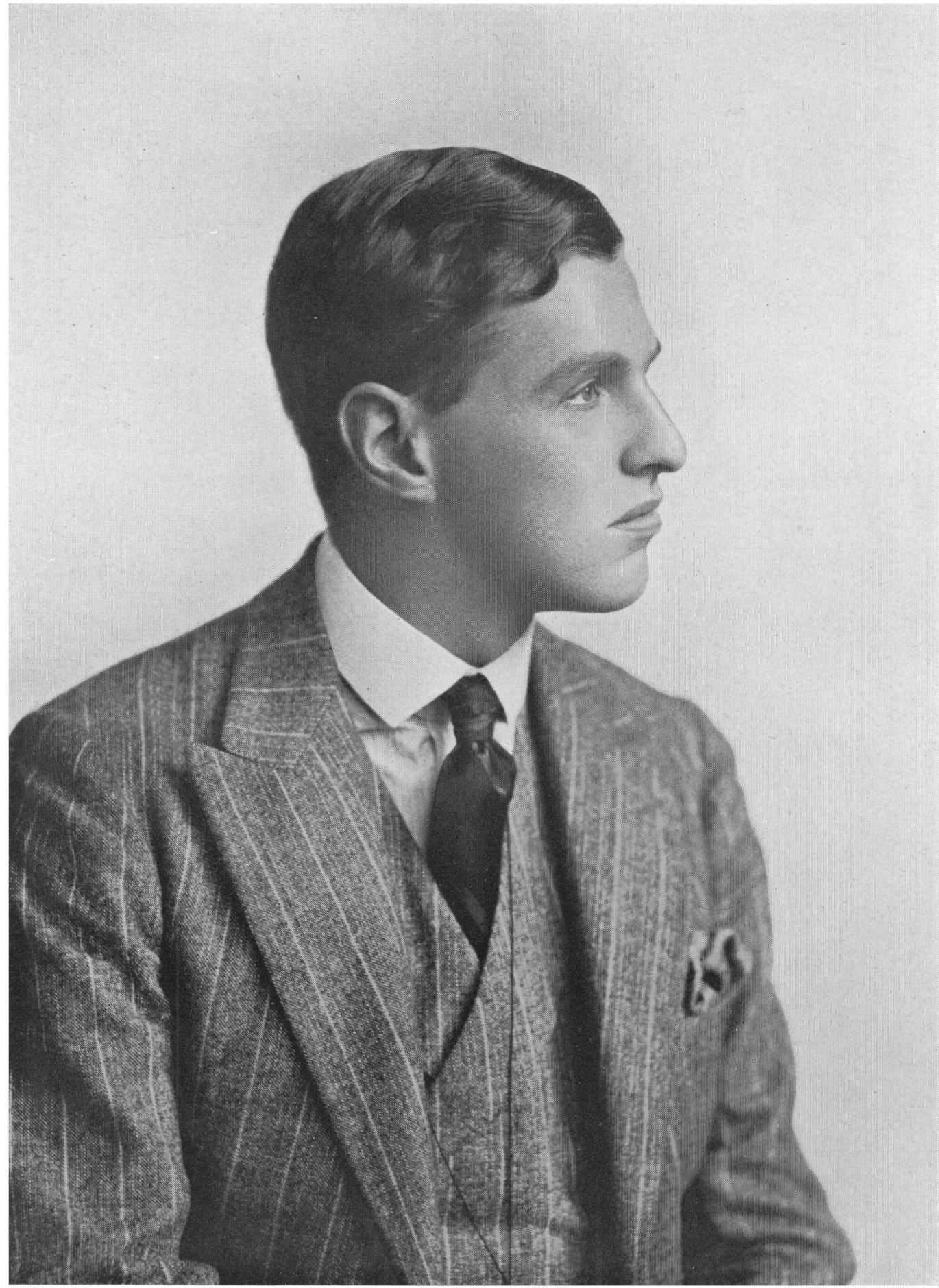

\section{JOHN DEVITT STRINGFELLOW PENDLEBURY. 1904-I94I.}

From the Journal of Egyptian Archaeology, Vol. 28, 1942, by kind permission of the Egyptian Exploration Society. 